\title{
Chapter 1 \\ On the Paleo-climatic/Environmental Impacts and Socio-Cultural System Resilience along the Historical Silk Road
}

\author{
Liang Emlyn Yang, Hans-Rudolf Bork, Xiuqi Fang, Steffen Mischke, \\ Mara Weinelt and Josef Wiesehöfer
}

\begin{abstract}
This chapter introduces, by literature reviews, the issue of the links and processes behind climate change, environmental change, and socio-culture change in the past at the ancient Silk Road region. Analyses of the changes of the socioenvironment system in this area enhance our understanding on the regular patterns of coupled natural and social evolution, and is thus of important theoretical and practical significance. We argue that the cross-cutting theme has been to reach beyond simple explanations of environmental or human determinism, but social resilience under environmental impacts. Studies indicate both that climate conditions significantly influence human socio-cultural systems and that the socio-culture systems are certainly resilient to climate impacts. This chapter also summarizes the scope of all chapters in this book by illustrating the specific topics, research areas, focused periods and their inner relationships. The conclusion further summarizes the recent research states on past socio-environmental dynamics and the findings achieved in this book, as well as some outlooks.
\end{abstract}

Keywords Paleo-climate change $\cdot$ Environmental stresses $\cdot$ Natural hazards Social resilience $\cdot$ Socio-culture system $\cdot$ The Silk Road

L. E. Yang $(\bowtie) \cdot$ M. Weinelt

Graduate School "Human Development in Landscape", Christian-Albrecht-Universität Kiel, Kiel, Germany

e-mail: lyang@gshdl.uni-kiel.de

L. E. Yang · M. Weinelt

Institute of Prehistoric and Protohistoric Archaeology, Christian-Albrecht-Universität Kiel, Kiel, Germany

H.-R. Bork

Institut für Ökosystemforschung, Christian-Albrecht-Universität Kiel, Kiel, Germany

X. Fang

Faculty of Geographical Science, Beijing Normal University, Beijing, China

S. Mischke

Faculty of Earth Sciences, University of Iceland, Reykjavík, Iceland

J. Wiesehöfer

Institute of Classical Antiquities, Christian-Albrecht-Universität Kiel, Kiel, Germany

(C) The Author(s) 2019

L. E. Yang et al. (eds.), Socio-Environmental Dynamics along the Historical Silk Road, https://doi.org/10.1007/978-3-030-00728-7_1 


\subsection{Introduction}

The Silk Road is a modern concept for an ancient network of trade routes that for centuries facilitated and intensified processes of cultural interaction and goods exchange between West China, Central Asia, the Middle East, and the Mediterranean (Elisseeff 2000). The term derives its name from the lucrative trade in Chinese silk carried out along its length. The Silk Road flourished when the Han Dynasty explored Central Asia around 139 BC and thrived throughout Antiquity and far into Middle Ages under the Islamic and Mongol Empires. However, the Silk Road network also often covers other earlier or regional routes, e.g. the Persian Royal Road established during the Achaemenid Empire (550-330 BCE) as well as the maritime connections between China and the West (Frankopan 2015) that are not involved in this chapter and the book. ${ }^{1}$ Though silk was certainly the major commodity, many other goods were traded, and religions, syncretic philosophies, and various technologies, as well as cultural influences, also spread along these networks. Trade and contacts on the Silk Road played a significant role in shaping the societies and cultures of ancient China, as well as those of the Mongols, Iranians, Arabs, Mesopotamians, Syro-Anatolians, Greeks and Romans, opening long-distance political and economic relations between various peoples and cultures (Bentley 1993; Frankopan 2015).

Along the ancient Silk Road, empires, dynasties and the associated institutions, social structures, and economic systems changed for several reasons. There is increasing discussion that climate and environmental factors might have also played a significant role in fostering economic and socio-cultural changes along the Silk Road as well as in a broader area (Zhang et al. 2011; Clarke et al. 2016). For instance, favorable environmental conditions may have boosted agriculture and animal husbandry, thus increasing the availability of resources necessary to support a powerful empire, while adverse conditions may have undermined the level of production and the living conditions of human society or exacerbated social stresses which eventually may have led to severe crises or collapse of socio-culture systems (Yang et al. 2017). In fact, coherent patterns and synchronous events in history suggest certain links between the social upheaval and climate forcing (Issar and Zohar 2004; Clarke et al. 2016), and environmental factors have been claimed as multipliers that accelerated socio-culture changes in some cases (Zhang et al. 2005; Rosen 2007).

However, it is also argued that many analyses over-emphasized the deterministic mechanisms (Gemenne et al. 2014). Research on climate change and social consequences primarily focuses on a few accessible regions, biasedly states the links between both phenomena and cannot explain the absence of social crisis in the face of climate risks (Adams et al. 2018). Indeed, archive-based studies of socio-economic responses to climate variability in colonial Mexico illustrate that vulnerability to change can lead to improved understanding of risks and increased adaptive capacity (Endfield 2012). At the same time, the possibility that social transitions themselves may have been responses/resilience strategies to abrupt climate events has also been

\footnotetext{
${ }^{1}$ The term Silk Road in this chapter thereafter and in the whole book indicates the overland Silk Roads as illustrated in Fig. 1.1, if not otherwise stated.
} 
under exploration (Clarke et al. 2016). Studies also provided evidence that diverse ethnics, religions, industries, business activities and physical environments supported the resilience of a port city development through long history along the North Coast of Java in Southeast Asia (Ariestadi et al. 2017). Increasingly in recent literature, studies on civilization resilience (Dunning et al. 2012), mountain resilience (Tinner and Ammann 2005), coastal resilience (Adger et al. 2005), urban resilience (Ernstson et al. 2010), community resilience (Gunderson 2010; Wilson 2014), etc., also indicated certain resilience capacities of human societies with various perspectives from the past to present, and at the same time, emphasized the significance of understanding resilience in a historical and holistic way.

Societal responses to external forces are nonlinear in nature (Leroy 2006), meaning that in the archaeological and historical records, any hypothesized direct linkages between cultural transition and environmental forcing must be treated with caution. Purely environmental explanations of societal collapse, including climatic explanations, remain less than convincing and are still controversially discussed to make a general conclusion (Endfield 2012). Different societies might pursue different adaptation strategies when faced with similar changes in climate, depending on existing environmental and cultural factors. Resilience and adaptation frameworks therefore help us move away from deterministic models of human-environment interaction and beyond existing causal models of climate-induced collapse (Brooks 2012). Bearing this in mind, links between climatic, environmental, economic, societal and cultural changes manifested themselves differently in different places and times and often remain unclear.

This chapter reviews, compiles and analyses published literature, environmental proxies alongside archaeological records, and strives to illustrate the state-of-theart in the field of socio-environmental interactions along the historical Silk Road areas. The introduction also briefly discusses the scope of other chapters in this book by illustrating the specific topics, research areas, focused time periods and their inner relationships to each other. We aim to highlight the complexity of the relationships between climatic and socio-cultural changes, and therefore encourage further investigations, for instance, of the concept of climate resilience that links both the climate impact and social response into one framework.

\subsection{Paleo-climatic/Environmental Changes and Impacts along the Historical Silk Road}

\subsubsection{The Physical Geography and Environmental Conditions}

The overland Silk Road is often recognized as a combination of the Desert Silk Road, Steppe Silk Road and the Southern Silk Road (the Tea-Horse Road) and covers a broad region of the Eurasian hinterland (Fig. 1.1). The most significant environmental characteristics of the region are dry sand deserts and Gobi (gravel desert), with 


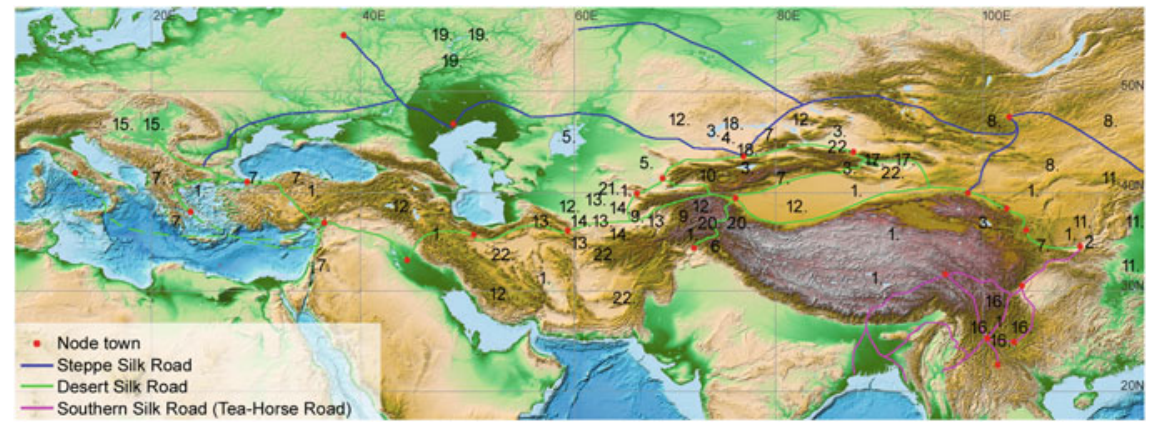

Fig. 1.1 Map of the historical overland Silk Road areas with rough representation of the road networks and node towns. Every number (chapter number in the book content) in the map indicates the main geographical location of the studies of a certain chapter in this book

high mountains including the Pamir, Tian-Shan, Karakoram and Hindukush. Another landscape characteristic of the region are the snow-fed rivers and oases that served as major places for human activities.

Geographically, the eastern areas of the Tian-Shan Mountains, mainly in the contemporary China, are complex with various local landscapes, including mountains, basins, deserts, Gobi, grasslands and oases (Yao et al. 2013). The Kunlun Mountains and Qilian Mountains at the northern margin of the Tibetan Plateau supported the predominant possibility for human exchanges along the foot hills in the east-west direction. There are only two possible pathways to go across the Tian-Shan Mountains, one is the southern foot hill line that passes over the Pamir at its western end, and another is the northern foot hill line that is a much longer alternative. The western side of the Tian-Shan Mountains represents typical grasslands in its north and deserts in the south (Hu et al. 2014). The grasslands compose a part of the Eurasia Steppe together with the Eastern European grasslands, while the deserts connect to the Iranian dry plateaus in the southwest. The Tarim River, Amu Darya, Syr Darya, and several lakes like the Lop Nur, Bosten, Balkhash and the Aral Sea form the main inland water bodies of the vast expanse of the drylands. Many oases fed by snow melting from the surrounding mountains are the major human settlement areas and provide stations for travelers. Due to the impacts of global climate warming and increasing human demands, most of the water bodies were shrinking significantly (Sorg et al. 2012).

The Desert Silk Road linked with the existing road networks in the Persian Plateau and further west-toward the Mesopotamia Basin and Anatolia (Frankopan 2015). The Persian Plateau and Anatolia are both surrounded by high arid mountains with sharp valleys. The central part of the Persian Plateau is a vast inland basin with dry salt marshes and deserts. The fertile Mesopotamia plain is surrounded by deserts, mountains and the Persian Gulf, where the Euphrates and Tigris Rivers flow almost in parallel from northwest to southeast and feed the alluvial plain (Fisher 2013). 
The Steppe Silk Road was formed at the north of the Aral Sea, Caspian Sea and the Black Sea, linking mainly local nomad people. The steppe belt covers wide temperate grasslands, savannas, and shrublands, where the relatively few and mobile nomad people did not develop large human settlements in the ancient times, and thus the trading roads were erratic (Christian 2000). The Southern Silk Road or "Tea-Horse Road" is an ancient Chinese commercial road network comparable to the traditionally known Silk Road (Forbe and Henley 2011). It is located in the Hengduan Mountains and the Tibetan Plateau and includes the Yangtze River (Jinsha River), Minjiang River, Nujiang River, Lancang River (Mekong River) and the Yarlung Zangbo River. The road networks originated from the Sichuan Basin of the ancient Chinese Empire and the major tea producing areas in Yunnan, and extended to Lhasa in the Tibetan Plateau and south to India across the Himalaya.

Generally, the natural environment at the historical Silk Road areas is very difficult for human living and traveling. The environmental conditions can be felt today and somehow also be imagined from ancient poems "yellow sands and dry grasses linking the land and sky" and traveling records "no flying birds, no walking animals, no living grasses". 3

\subsubsection{Paleo-climatic/Environmental Changes and Social Impacts}

Over the $\sim 12$ millennia period of the Holocene, the climate in arid Asia has fluctuated. It has experienced the early Holocene warming period (11700-8500 years BP (Before Present)), the mid-Holocene warm period (8500-3000 years BP), and the late Holocene cooling and drought period (from 3000 years BP to present). Chen et al. (2008) confirmed that during the early Holocene most of the lakes in the region experienced very low water levels or even dried out before ca 8000 years BP. The study based on loess grain-size changes of loess sediments in the Ili Basin by Li et al. (2011a) also recorded the warm and dry period of 11000-8000 years BP.

Small climate fluctuations in each large period are still relatively consistent. Several cold climate periods around 8200, 5000, 4200, 3100 and 600 years BP occurred in almost every sub-region (Mayewski et al. 2004), which generally showed significant continental and arid climatic characteristics in Central and West Asia. As a result of paleo-environmental syntheses based on several types of proxy data, it is accepted that the mid-Holocene drought reached its peak between 3800 and 3500 years BP (Arikan 2015). However, some humid periods occured in middle to late Holocene as evidenced by loess records in Xinjiang (Chen et al. 2016) and Iran (Chen et al. 2017), which had a profound impact on the development of human civilization in the inland dry areas in Asia.

\footnotetext{
${ }^{2}$ Cen Shen, Remember Duling at Jiuquan. 岑参, 《过酒泉, 忆杜陵别业》.

${ }^{3}$ The biography of Master Sanzang. Tang Dynasty. 沙门慧立本, 释彦悰䇝. 《大慈恩寺三藏法师传》, 10 卷.
} 
Overall, the traditional Silk Road area has a distinctive semi-arid climate with hot, cloudless, dry summers and moist, relatively warm winters in the south and cold winters with severe frosts in the north. Precipitation throughout most of the region has a spring maximum (Lioubimtseva and Henebry 2009). Records of stalagmites from Kesang Cave demonstrate that precipitation history in the region exhibits a processional rhythm over most of the past 500,000 years (Cheng et al. 2012). Based on the early-to-mid-Holocene reconstructions, the arid zones of Central Asia may become moister as a result of global warming, due to an expected southward shift and probable intensification of the westerly cyclones (Lioubimtseva and Henebry 2009). However, due to the very high uncertainty in such studies, it is important to further understand the mechanisms of precipitation changes and climate in general.

Oasis systems play a dominant role in supporting human activities in the arid Asia, but they are fragile to large-scale climate change and also human influences. For instance, the eco-environment of the oasis systems in the southern part of the Tarim Basin has taken great changes during the recent 2000 years, which are characterized by the evolution and desertification of oasis and led to many famous ancient cities having been abandoned ( $\mathrm{Zu}$ et al. 2003; Liu et al. 2016). However, research based on analyses of lake sediments from Lop Nur in the eastern Tarim Basin also shows that the Loulan Kingdom decline resulted from a man-made environmental disaster rather than from changing climate, because lakes in adjacent regions recorded rising levels and relatively wet conditions during the same period (Mischke et al. 2017). Analyses on the distribution and evolution of oases show that environmental changes are partly due to the aridization of climate before the 20th century but mainly attributed to the human activities in the 20th century.

The environments in the Silk Road areas are complex and diverse, and the climate is sensitive and variable. The development of regional cultures was deeply influenced by the natural environment and its evolution (McMichael 2012). Tree ring-based reconstructions of European summer precipitation and temperature variability over the past 2500 years revealed human susceptibility to climate variability (Buntgen et al. 2011). The direct manifestation of climate impacts may be in terms of its resource utilization and economic shape of human society, while the extensive influences can contribute to the development, migration, spreading and the rise and fall of cultures. Abrupt climate change events, such as the widespread droughts around 8200, 5200 and 4200 years BP, are suggested to be the result of altered subtropical upper-level flow over the eastern Mediterranean and Asia (Staubwasser and Weiss 2006).

In monsoonal Asia, drastic swings in moisture availability, notably megadroughts associated with monsoon failure, interacted with socio-political and technical institutions to spur the disintegration of the 14th century Khmer Kingdom at Angkor (Hessl et al. 2017). The late 16th and early 17th century experienced a period of drought and the collapse of the Ming Dynasty in China, while most of the regions across Southeast Asia saw great unrest and rapid realignment during one of the most extended periods of drought (Buckley et al. 2014). New paleo-proxy records and the incorporation of historical documentation are expected to further improve the understanding of these disruptions in regional societies. 
Looking at the natural environment and cultural development of late Holocene period in the Silk Road areas, we could see the following salient features:

- First, when the climate developed toward dry-cold or warm-humid, the vegetation belt in Eurasia moved southward or northward accordingly (Li et al. 2011b; Zhao et al. 2017; Dallmeyer et al. 2017). In most cases, the climate shifts drove people of different economic modes move to the south or north as well. As a result, a boundary line between agriculture (oasis regions) and pastoralism groups (steppe areas) was formed. In China, the line was stretched to a belt region approximately equivalent to the position of the Great Wall (Shi et al. 2017).

- Second, the north-south movement of human groups is often accompanied by wars and conflicts, especially between the agricultural and non-agricultural groups (Cosmo 2002; Zhang et al. 2007). As a result, cultures and blood was often exchanged between both regions.

- Third, the social development model associated with local environment was also formed over long periods of time, for example, the oasis agriculture mode and the steppe pastoralism mode (Porter 2012). These modes were formed and developed relatively slowly but were compatible with the harsh natural environment.

- Fourth, in several extreme climatic periods of the last 5000 years, the different socio-economic modes and their coping strategies have brought about distinctly different results in terms of society, economy and culture that some successfully transformed and some collapsed (Fang and Zhang 2017).

In general, the development level of culture and productivity in arid Asia was limited during most of the Holocene period. However, human societies were always learning to adapt to environmental changes and influences. Similar to results of Tol and Wagner (2010) for Europe, the relationship between social conflicts and climate varies weakens in the industrialized era, and is not robust to the details of climate conditions in many contemporary societies. It often seems that human beings were passively adapting to nature, but essentially it might also be a process of continuous learning and active response.

\subsection{Socio-Cultural Dynamics and Resilience in a Historical Perspective}

\subsubsection{Socio-Cultural Features and Exchanges along the Silk Road Areas}

Cold mountains, dry deserts and seasonal grasslands composed the complex and diverse landforms of most areas along the historical Silk Road, which are tough conditions for human activities in ancient times. However, our ancestors were not isolated by the unfavorable geographical conditions. There are often rivers flowing down from the snow-capped mountains on the edge of the deserts, which irrigated 
oases and served as cradles of local socio-cultural development and exchange places of different civilizations. The Silk Road connected these places and people and major civilizations in the Eurasian continent, including the Confucian in Eastern Asian, Buddhism-Hinduism in Southern Asian, Islam civilization in Western Asian, and the Greek-Roman civilization in Europe (Beckwith 2009). Its strategic and historic position around the East-West axis and the major trading routes guaranteed a steady influx of ideas and conflicting notions of tribalism and traditionalism, and stimulated a variety of cultures such as the Buddhism, Mongols, Persians, Tatars, Russians and Sarmatians (Liu 2010).

From the 2nd century BC to the 2 nd century AD, four empires juxtaposed along the historical Silk Road from west to east. That is, the Roman Empire in Europe (30 BC-284 AD), the Parthian Empire in West Asia (247 BC-224 AD), the Kushan Empire in Central Asia (30-375 AD), and the Han Dynasty of East Asia (206 BC-220 $\mathrm{AD})$. The four empires were in a period of prosperous states around the 1st year AD and were actively expanding outward. Their pioneering efforts directly connected the East and West worlds and enhanced the mutual exchanges and influences between the four ancient civilizations of China, India, Persia and Greece (Beckwith 2009). Since then, the development of any civilization has not been carried out in isolation.

The ancient Silk Road contributed greatly to the cultural exchange between China and the West. From the 2nd century BC to the 15 th century AD, splendid cultures among China, India, Greece, Persia and Rome were exchanged along this famous trade route, making the route a great "Cultural Bridge" between Asia and Europe (Foltz 2010). Religion is of great importance in most places, but this is especially true in the Silk Road areas where the culture cannot be separated from religious beliefs and practices. In the 1 st century AD, Manicheism and Christianity penetrated from the Near East to Central Asia and further to China. Islamic doctrine might have been brought by warriors of Arabian caliphates in the 7th century but its distribution along the Silk Road was carried out peacefully. At the same time, the Silk Road was also the route for Buddhist monks who went from India to Central Asia and China (e.g. the most known monks Zhu Shixing, Fa Xian, and Xuan Zang) (Liu 2010), as well as the route for Christian doctrine dissemination. The most significant religion in the Silk Road areas, by far, is Islam that dominants in the southern and western parts, while the northern steppe areas are more related to the Russian Orthodox Church (Foltz 2010). The Southern Silk Road regions had a significantly different culture reflecting a mixture of Chinese Buddhism, Tibetan Buddhism and many local religions.

Central Asia was once the center of multiple nomadic empires and tribes, including the Scythians, Mongols and Turks. The invasions and migrations of nomads were an important force in history that greatly affected all parts of Eurasia and also influenced the traditions and cultures of many Silk Road sub-regions to the present day. A big shock occurred from the 2nd century BC when the Xiongnu nomadic tribes raised and moved from the east to west in the steppe (Wu 1983). This movement led to a series of nomadic intrusions into the farming empires such as the Chinese Qin-Han Dynasties, the Indian Kushan Empire and the Western Roman Empire. In the 13th century, another big wave of the impact of the nomadic world on the farming world broke out, when the Mongols and Turkic people attacked the whole region along the 
Silk Road from East Asia to Central Europe (Wu 1983). The interaction between farming civilization and nomadic civilization was an important way to promote the development of civilization in Eurasia. So dynamic were the steppes that vast empires could rise and fall within a generation (Invictus 2006). In the modern era, with the ultimate decline of nomadic cavalry and the rise of maritime trades, the nomadic Eurasia gradually lost its military superiority to the surrounding farming civilizations.

The Silk Road was not only the source of goods but also information on their making, i.e. technologies, in particular, the breeding of silkworms, silk spinning, paper making, printing with movable types, the making of gunpowder, porcelains and lacquers, and the invention and use of the compass. Material culture exchange was also underway on this long trade road (Liu 2010). A large number of products of the West flowed into China, such as grapes, walnuts, carrots, peppers, spinach, cucumbers, pomegranates, medicinal materials, flavorings and jewelry. Also, along with spreading goods, cultural developments in the applied art, architecture, wall painting, music and dances enriched the intercultural exchange along the Silk Road (Elisseeff 2000). The cultural exchange between China and the West offered mutual benefits and achieved common progress, which greatly sped up the development of the Eurasia world.

\subsubsection{Resilience of the Socio-Cultural Systems}

Climatic change has certainly influenced socio-culture characters in the long (pre-)history of the Eurasian continent, while it can also be a factor of technological innovations in order to compensate difficulties and to maintain a certain threshold of vital yields for the whole population, such as moving to new ecological areas and adapting new irrigation or planting techniques (Clarke et al. 2016; Flohr et al. 2016). Actually, the diversity of cultures, livelihoods, and political formations indicated that relationships between climate, ecosystems, and societies are non-linear, complex, and variable over time (Endfield 2012). Examples of human-environment interactions in the monsoonal and arid Central Asia suggested that societies have adjusted to climate variability in diverse and (mal)adaptive ways over the last three millennia (Hessl et al. 2017).

It has recently been emphasized that the concept of social resilience can be usefully deployed in some historical contexts (Haldon and Rosen 2018). Among the five patterns of the impacts of climate change on civilization summarized by Fang and Zhang (2017), only one is socio-cultural collapse while the other four are different types of resilient continuous cultures and transformations of socio-cultural systems. It is a normal phenomenon in the Silk Road areas that a group of people (e.g. nomadic tribes) migrate to another area after consuming the resources of one area. This kind of migration is not a manifestation of social system collapses. On the contrary, it is the performance of the social system with resilience and adaptability.

History and archaeology have a well-established engagement with issues of premodern societal development and the interaction between physical and cultural envi- 
ronments; together, they offer a holistic view that can generate insights into the nature of cultural resilience and adaptation (Haldon et al. 2018). The so-called 9.2 and $8.2 \mathrm{ka}$ events were among the most pronounced and abrupt Holocene cold and arid events in the Northern Hemisphere and especially in Southwest Asia. However, a thorough study did not show evidence for a simultaneous and widespread social collapse, large-scale site abandonment, or migration at the time of the events, instead, there are indications for local adaptation (Flohr et al. 2016). This result could lead to the conclusion that early farming communities were somehow resilient to the abrupt, severe climate changes.

Modeling tools have the advantage to represent the process of human responses under climatic and environmental stresses. An agent-based model indicated that highly interconnected social systems without mobility are less effective in adaptition to climate impacts, while they jointly as a larger social unit can be more resilient than the individuals (Rogers et al. 2012). The case analysis at Gordion in central Turkey implicated temporal and spatial mismatches as a cause for local environmental degradation, and increasing extra economic pressures as an ultimate cause for the adoption of unsustainable land-use practices (Marston 2015). Integrated analyses of palaeoclimate proxies and model simulations also reveals the limited extent in which climate trends determine patterns of socio-economic activities in complex historical societies (Xoplaki et al. 2018). These analyses suggest that a research approach which integrates environmental archaeology with a resilience perspective has considerable potential for explicating regional patterns of agricultural change and environmental degradation in the past.

Still, it is often unclear which characters a social system must have to be resilient. Peregrine (2017) examined 33 archaeologically known societies bracketing 22 catastrophic climate-related disasters and concluded that societies allowing greater political participation appear to provide greater resilience to catastrophic climate-related disasters, which generally supports the predominant perspective in recent disaster response studies. Another opinion is that human societies gained increasing abilities and productivities to not only adapt but also "reform" the natural environment since the traditional farming technologies emerged from the 3rd-4th century BC in China (The Warring States Period) (Han 2008). In other words, this also means that human impacts on the natural environment have significantly increased. For instance, many oasis grasslands were changed into farmlands when the Han Dynasty attached Xiongnu and opened the Desert Silk Road, which brought irreversible damages to the natural desert-oasis environment.

Apparently, discussions of significant climate impacts on social systems so far have focused on ancient agricultural and pastoral societies because these societies are more sensitive to climatic and environmental conditions. On the contrast, very few studies discussed climate-society relationships after the Industrial Revolution or in industrialized countries. A broad consensus is that technology and economic development can increase the resilience and resistance of human social systems and mitigate the negative impacts of climate change (Adger et al. 2009). As the correlation between climate and society is weakening and even negative, it appears that global warming would not lead to an increase in social conflicts in warmer climates 
(Tol and Wagner 2010). It can be assumed that as long as the climate conditions do not undergo large-scale dramatic changes, the socio-cultural systems would unlikely be completely destroyed at one time. Social and cultural characteristics (e.g. stability of core territory and the main ethnic groups) can thus still achieve cumulative development. However, in comparison with the topic of climate impacts on society, societal responses to climate changes have far less been explored. This is right the direction that this chapter and the book are dedicated to.

\subsection{Book Overview and Key Messages}

\subsubsection{Coverage of the Book}

Independent studies on the natural environment and social development of the Silk Road region began in the early 20th century. So far, the academic community has basically defined the routes network and the areas along the Silk Road, and built up a general understanding of the natural environment and social conditions. There are also a number of studies investigating local specific human-environment relations. Despite this state of research, there is still a lack of comprehensive research focusing on the social and environmental development of the entire Silk Road area in its long past. Therefore, the core purpose of this book is to discuss the socio-cultural changes that took place in the Silk Road area where climate/environmental proxies indicate rapid and/or high amplitude changes and impacts.

The book has 22 chapters. Versions of most of the chapters were initially prepared for the international workshop entitled "The Rise and Fall: Environmental Factors in the Socio-Cultural Changes of the Ancient Silk Road Area”, which was convened at the Kiel University during September 27-28, 2017. Each chapter has a specific topic focusing on a specific geographical region, and as a whole the book covers most of the overland Silk Road areas (Fig. 1.1). The chapters are divided into six parts based on the related topics. An overview of each part and associated key messages are provided below.

\subsubsection{Key Messages from the Book}

The first part of the book is this introduction paper (Chap. 1; Yang et al. 2019). It first reviewed the state-of-the-art on socio-environmental dynamics in the historical Silk Road areas and then introduced the scope of all chapters in this book by illustrating the specific topics, research areas, focused time periods and their inner relationships to each other. The introduction further summarizes the findings achieved in this book, as well as some outlooks. The chapter also discusses some key concepts and 
definitions that are deemed useful for examining resilience and vulnerability from an archaeological perspective.

The second part includes five studies on landscape evolutions in the humanenvironment system (Chaps. 2-6). The concept of landscape has for quite a long time been important to geo-scientists and environmental scientists in understanding human-environment systems, which is well reflected in the chapters about drying lakes in western China (Fei et al. 2019; Mischke et al. 2019). In Central Asia, hydrogeological systems evidenced human colonization, and the impacts of water extractions on tributaries of large river and lake systems are suspected as the main causes of water level regressions in the Ili River Delta (Deom et al. 2019) and the Aral Sea (Sala 2019). The chapter of Spate (2019) synthesized past archaeological and climate data in Kashmir and concluded that differentiated landscape patterns may have resulted from long-term adjustment and reorganization as a response to climate pressures.

Part III of the book consists of a series of four papers (Chaps. 7-10) that are arranged under the topic of natural disasters and impacts. The Silk Road areas overlap well with the earthquake and mountain fault belt that runs from China to Italy, and thus many local earthquake-resistant techniques were developed in sub-regions (Kázmér 2019). The study on climate-related dryness, famine and diseases in the Eastern Turkic Empire suggested that the climatic factor did have an impact on the historical processes that took place in the nomadic territories (Ganiev and Kukarskih 2019). As we stated before, dryness is the major natural threat for most of the Silk Road areas especially over the last millennium when human activities have increased dramatically (Opała-Owczarek and Owczarek 2019; Chen et al. 2019).

The book includes a major part investigating climate impacts on social systems (Part IV, Chaps. 11-15). Analysis of global climate simulations over the last 6000 years indicate that $10 \%$ more precipitation may have provided the climatological foundation for the golden era of Silk Road trades (Hill 2019). Even in adverse climate conditions, social adaptation activities helped to avoid hardship and expanded the capabilities for the continual development of the Chinese civilization (Fang et al. 2019). In Central Asia and Western Asia, inferences of Turkic tribes' migration in Saljūqs period reach beyond climatological determinism and provide more sociopolitical explanations (Frenkel 2019). And, Luneau (2019) argues that the present data do not support a drastic climate change during the first half of the 4th millennium BP as a responsible factor for the fall of the Oxus civilization. Pow (2019) also questions the climatic and environmental effects on the Mongol Empire's withdrawal from Hungary in 1242. A common message from these articles is that climate impacts are recognized but not considered as a dominant factor in the development of social events.

The fifth part of the book includes four papers of social adaptation and resilience to environmental stresses (Part V, Chaps. 16-19). Experience of extreme climate conditions can increase opportunities for learning and innovation, e.g. local people developed hydraulic systems of water-sediment separation at the mountainous TeaHorse Road region that effectively mitigated flood hazards (Xu et al. 2019), and the Karez system in the dry Asian regions is a great human creation that survives 
social development for thousands of years (Mächtle et al. 2019). The study from Panyushkina et al. (2019) shows that Saka people of the Iron Age employed extensive ravine agriculture on alluvial fans and that they were able to apply simple flow control structures, which certainly reduced water constrains to agricultural expansion in the Lake Balkhash Basin. The steppe landscape in the Middle Volga region was also transformed by cultivation, wood extraction, and the expansion of pastures and road networks in the past 2500 years (Vyazov et al. 2019). These examples from the past might help inform the degree to which societies can develop strategies to deal with environmental perturbations at different scales and highlight that social breakdown and collapse are not an inevitable result of transformation.

The last part of the book discusses three environment-related socio-cultural issues (Part VI, Chaps. 20-22). Studying early rock carvings in the Karakoram Ranges gains insight into the roots and spread of early Buddhism in the extreme dry-cold-high environment (Aerde 2019). The chapter by Marten-Finnis (2019) reveals how ecological zones and their division into steppe and sown, nomadic and sedentary people, helped Russian ethnographers to understand the heritage and urban neighborhood principles of Bukhara. In addition, Abudu et al. (2019) review the Karez systems from the perspective of the cultural heritage, and argue that Karezes should be protected as indigenous human heritage and utilized to enhance water resilience under changing environments.

Overall, human societies have always been living with and adapting to a variable climate and environment. It is clear from studies in this book that climate has certainly influenced human societies while societies have also shown increasing resilience and capability in coping with adverse climate impacts. The Silk Road areas are richly endowed with information on human and environmental history, which makes it suitable for exploring interactions between climate, environment and humans over a variety of time scales. As historians, archaeologists, geographers, paleo-environmentalists and paleo-climatologists, we often seek to contribute to a better understanding of this complex topic. This book is an important step in this direction.

The concept of social resilience has gradually become an important topic in scientific communities (e.g. Climatology, Geography, Socio-ecology, Geoarchaeology, and Sustainability). In fact, increasingly sophisticated detection and attribution studies already suggest that societies have largely persisted and developed continuously in hazard-prone areas and climate-change periods. Findings and discussions of chapters in this book make evident that many challenges remain which are connected to even more complex questions for forthcoming research:

- Are there clear cases of social resilience to climate changes in the past societies? If so, what are the general environmental-socio-cultural patterns?

- What are the key factors and features for a social system to be resilient in face of climate variation? In other words, how can resilience be maintained in key sectors, e.g. agriculture, nomadism, livelihood, population and urbanization?

- How did social resilience change and evolve in response to climate changes? What are the scope, thresholds and tipping points for the dynamics of social resilience? 
- What can we learn from the experience and lessons of the past resilient and/or "un-resilient" societies? Are these learnings up-scalable to explanatory theories?

These are open questions that some chapters in this book addressed but which were not deeply investigated yet. In order to both forecast and adapt to future conditions we need to advance our understanding of interactions between cases of sociocultural resilience to climate change in time and space, and to utilize the knowledge in supporting sustainable development at local, regional and global levels.

\subsection{Summary and Outlook}

The development of the Silk Road has supported a great leap of long-distance, largeamount cultural exchange across the Eurasian continent, and has had a profound impact on the overall development of human society. Studies on the rise and fall of the Silk Road have shown some principles of human-climate relationships. Climate conditions can lead to the abandonment of villages or castles but that does not necessarily mean a collapse of the human society. People are active and social systems are able to migrate or adapt. Migration is not a manifestation of the collapse of the socio-cultural system, on the contrary, it shows the resilience of the system.

Today, the Silk Road has become a road of friendship for economic and cultural exchanges between Asia, Europe, Africa and even further areas. The Silk Road was declared a World Heritage Site by UNESCO in 2014. China's recent "Belt and Route Initiative" further promotes attentions to the traditional Silk Road areas. On the one hand, the Silk Road has become a popular word through cinema, television and other popular media. On the other hand, however, the Silk Road has so far majorly been discussed in politics and business themes from the East side (e.g. China's business attempts) while its reception in sciences are less targeted. It remains a challenge for research to overcome the chronological, regional, linguistic, and disciplinary fragmentation of Silk Road research. However, the fact that the term is a modern construct, makes it a fruitful, organizational concept for the scholarship. By constructed definition, it could also allow and promote transnational, superregional, intercultural and interdisciplinary approaches to research and comprehension.

The Loulan Kingdom at Lop Nur region used to be an ancient country with animal husbandry and oasis agriculture in the center of the Silk Road areas. Sima Qian wrote in his "Historical Records" (1st century BC) that "Loulan is rich of jade, reed, poplar trees and white grass. The people often move to where there are water and grasslands". ${ }^{4}$ However, when Xuan Zang passed by this area in the Tang Dynasty (7th century $\mathrm{AD}$ ) he saw only "remains of towns and castles, but no people anymore". 5 This tragic change happened with both impacts from natural environment change and human activities. Research on the environmental changes, social development,

\footnotetext{
${ }^{4}$ Sima Qian, 91 BC. Historical Records. 司马迁在《史记》中记载: “楼兰出玉,多臀苇、柽柳、胡杨、白草,

${ }^{5}$ Xuan Zang (talk), Bian Ji (write), 646 AD. Great Tang Records on the Western Regions. 《大唐西域记》: “城郭崩然, 人烟断绝”.
} 
the rise and fall process, and their interactions along the Silk Road can provide important historical experience and decision-making basis for regional sustainable development in present times, and is thus of theoretical and practical significance.

A growing network of multi-millennial, multi-proxy records from multiple subregions would help reveal climatic contexts for more important historic events which emphasize the diversity of human-environment interactions. Future efforts in this field will need to account for the diversity of economic, political, and cultural features that filter, dampen, and amplify the effects of climate change on society. This chapter and the book hold the concept of "taking history as a mirror", and hope to promote more studies on the evolution process of environmental-social interactions, in both the Silk Road areas and other regions.

Acknowledgements This introduction chapter, as part of the book volume, emerged as a result of a workshop at Kiel University, Germany in September 2017, addressing the socio-culturalenvironmental changes of the ancient Silk Road areas. The workshop and the editing of the book were jointly supported by the Graduate School Human Development in Landscapes at the Kiel University (GSC 208/2) and the Past Global Changes project (PAGES).

\section{References}

Abudu, S., Sheng, Z., King, J. P., \& Ahn, S.-R. (2019). A Karez system's dilemma: A cultural heritage on a shelf or still a viable technique for water resiliency in arid regions? In L. E. Yang, H.-R. Bork, X. Fang, \& S. Mischke (Eds.), Socio-environmental dynamics along the historical silk road. Heidelberg, Germany: Springer-Nature Press.

Adams, C., Ide, T., Barnett, J., \& Detges, A. (2018). Sampling bias in climate-Conflict research. Nature Climate Change, 8(3), 200-203. https://doi.org/10.1038/s41558-018-0068-2.

Adger, W. N., Dessai, S., Goulden, M., Hulme, M., Lorenzoni, I., Nelson, D., et al. (2009). Are there social limits to adaptation to climate change? Climate Change, 93(3-4), 335-354.

Adger, W. N., Hughes, T. P., Folke, C., Carpenter, S. R., \& Rockstrom, J. (2005). Social-ecological resilience to coastal disasters. Science, 309(5737), 1036-1039.

Aerde, M. V. (2019). Routes beyond Gandhara: Rethinking early Buddhist rock carvings: Bridging cultural and environmental studies of the ancient Silk Roads. In L. E. Yang, H.-R. Bork, X. Fang, \& S. Mischke (Eds.), Socio-environmental dynamics along the historical silk road. Heidelberg, Germany: Springer-Nature Press.

Ariestadi, D., Sudikno, A., Wulandari, L. D., \& Surjono, S. (2017). Resilience of historical urban multi-ethnic settlement: Entrepreneurship and religiosity concept of Gresik city. In IOP Conference Series: Earth and Environmental Science 99:012026.

Arikan, B. (2015). Modeling the paleoclimate (ca. 6000-3200 cal BP) in Eastern Anatolia: The method of macrophysical climate model and comparisons with proxy data. Journal of Archaeological Science, 57, 158-167.

Beckwith, C. I. (2009). Empires of the Silk Road: A history of central Eurasia from the bronze age to the present. Princeton: Princeton University Press. ISBN: 978-0-691-13589-2.

Bentley, J. H. (1993). Old world encounters: Cross-cultural contacts and exchanges in pre-modern times. Oxford, UK: Oxford University Press.

Brooks, N. (2012). Beyond collapse: Climate change and causality during the Middle Holocene climatic transition, 6400-5000 years before present. Geografisk Tidsskrift-Danish Journal of Geography, 112(2), 93-104. 
Buckley, B. M., Fletcher, R., Wang, S. Y. S., Zottoli, B., \& Pottier, C. (2014). Monsoon extremes and society over the past millennium on mainland Southeast Asia. Quaternary Science Reviews, 95, 1-19.

Buntgen, U., Tegel, W., Nicolussi, K., McCormick, M., Frank, D., Trouet, V., et al. (2011). 2500 years of European climate variability and human susceptibility. Science, 331(6017), 578-582.

Chen, F., An, C., Dong, G., \& Zhang, D. (2017). Human activities, environmental changes, and rise and decline of silk road civilization in pan-third pole region. Proceedings of the Chinese Academy of Sciences, 32(9), 967-975.

Chen, F., Yu, S., He, Q., Ermenbaev, B., \& Satylkanov, R. (2019). A drought reconstruction from the low-elevation juniper forest of Northwestern Kyrgyzstan since CE 1565. In L. E. Yang, H.-R. Bork, X. Fang, \& S. Mischke (Eds.), Socio-environmental dynamics along the historical Silk Road. Heidelberg, Germany: Springer-Nature Press.

Chen, F. H., Jia, J., Chen, J. H., Li, G. Q., Zhang, X. J., Xie, H. C., et al. (2016). A persistent Holocene wetting trend in arid central Asia, with wettest conditions in the late Holocene, revealed by multiproxy analyses of loess-paleosol sequences in Xinjiang, China. Quaternary Science Reviews, 146, 134-146.

Chen, F. H., Yu, Z. C., Yang, M. L., Ito, E., Wang, S. M., Madsen, D. B., et al. (2008). Holocene moisture evolution in arid Central Asia and its out-of-phase relationship with Asian monsoon history. Quaternary Science Reviews, 27(3-4), 351-364.

Cheng, H., Zhang, P. Z., Spotl, C., Edwards, R. L., Cai, Y. J., Zhang, D. Z., et al. (2012). The climatic cyclicity in semiarid-arid Central Asia over the past 500,000 years. Geophysical Research Letters, 39(1).

Christian, D. (2000). Silk Roads or Steppe Roads? The Silk Roads in world history. Journal of World History, 11(1), 1-26.

Clarke, J., Brooks, N., Banning, E. B., Bar-Matthews, M., Campbell, S., Clare, L., et al. (2016). Climatic changes and social transformations in the Near East and North Africa during the 'long' 4th millennium BC: A comparative study of environmental and archaeological evidence. Quaternary Science Reviews, 136, 96-121.

Cosmo, N. D. (2002). Ancient China and its enemies: The rise of nomadic power in East Asian history. Cambridge: Cambridge University Press.

Dallmeyer, A., Claussen, M., Ni, J., Cao, X. Y., Wang, Y. B., Fischer, N., et al. (2017). Biome changes in Asia since the mid-Holocene-An analysis of different transient earth system model simulations. Clim. Past, 13(2), 107-134.

Deom, J.-M., Sala, R., \& Laudisoit, A. (2019). The Ili River Delta: Holocene hydrogeological evolution and evidence of Bronze Age colonization. In L. E. Yang, H.-R. Bork, X. Fang, \& S. Mischke (Eds.), Socio-environmental dynamics along the historical Silk Road. Heidelberg, Germany: Springer-Nature Press.

Dunning, N. P., Beach, T. P., \& Luzzadder-Beach, S. (2012). Kax and kol: Collapse and resilience in lowland Maya civilization. Proceedings of the National Academy of Sciences of the United States of America, 109(10), 3652-3657.

Elisseeff, V. (2000). The Silk Roads: Highways of culture and commerce. UNESCO, integral study of the Silk Roads: Roads of dialogue. New York: Berghahn Books.

Endfield, G. H. (2012). The resilience and adaptive capacity of social-environmental systems in colonial Mexico. Proceedings of the National Academy of Sciences of the United States of America, 109(10), 3676-3681.

Ernstson, H., van der Leeuw, S. E., Redman, C. L., Meffert, D. J., Davis, G., Alfsen, C., et al. (2010). Urban transitions: On urban resilience and human-dominated ecosystems. Ambio, 39(8), $531-545$.

Fang, X., Su, Y., Wei, Z., \& Yin, J. (2019). Social impacts of climate change in historical China. In L. E. Yang, H.-R. Bork, X. Fang, \& S. Mischke (Eds.), Socio-environmental dynamics along the historical Silk Road. Heidelberg, Germany: Springer-Nature Press.

Fang, X., \& Zhang, D. (2017). Patterns of the impacts of climate change on civilization. Advances in Earth Science, 32(11), 1218-1225. 
Fei, J., He, H., Yang, L. E., Li, X., Yang, S., \& Zhou, J. (2019). Evolution of Saline Lakes in the Guanzhong Basin during the past 2000 years inferred from historical records. In L. E. Yang, H.-R. Bork, X. Fang, \& S. Mischke (Eds.), Socio-environmental dynamics along the historical Silk Road. Heidelberg, Germany: Springer-Nature Press.

Fisher, W. B. (2013). The middle east: A physical. Routledge, London, UK: Social and Regional Geography.

Flohr, P., Fleitmann, D., Matthews, R., Matthews, W., \& Black, S. (2016). Evidence of resilience to past climate change in Southwest Asia: Early farming communities and the 9.2 and 8.2 ka events. Quaternary Science Reviews, 136, 23-39.

Foltz, R. (2010). Religions of the Silk Road: Premodern patterns of globalization. New York: Palgrave Macmillan.

Forbe, A., \& Henley, D. (2011). China's ancient Tea Horse Road. Cognoscenti Books, Chiang Mai, Thailand.

Frankopan, P. (2015). The Silk Roads: A new history of the world. London: Bloomsbury Publishing.

Frenkel, Y. (2018). The coming of the Barbarians-Can climate explain the Saljūq s' advance? In L. E. Yang, H.-R. Bork, X. Fang, \& S. Mischke (Eds.), Socio-environmental dynamics along the historical Silk Road. Heidelberg, Germany: Springer-Nature Press.

Ganiev, R. T., \& Kukarskih, V. V. (2019). Natural disasters in the history of the Eastern Turk Empire. In L. E. Yang, H.-R. Bork, X. Fang, \& S. Mischke (Eds.), Socio-environmental dynamics along the historical Silk Road. Heidelberg, Germany: Springer-Nature Press.

Gemenne, F., Barnett, J., Adger, W. N., \& Dabelko, G. D. (2014). Climate and security: Evidence, emerging risks, and a new agenda. Climate Change, 123(1), 1-9.

Gunderson, L. (2010). Ecological and human community resilience in response to natural disasters. Ecology and Society, 15(2).

Haldon, J., Mordechai, L., Newfield, T. P., Chase, A. F., Izdebski, A., Guzowski, P., et al. (2018) History meets palaeoscience: Consilience and collaboration in studying past societal responses to environmental change. Proceedings of the National Academy of Sciences of the United States of America, 115(13), 3210-3218. https://doi.org/10.1073/pnas.1716912115.

Haldon, J., \& Rosen, A. (2018). Society and environment in the East Mediterranean ca 300-1800 CE. Problems of resilience, adaptation and transformation. Introductory essay. Human Ecology, 46(3), 275-290. https://doi.org/10.1007/s10745-018-9972-3.

Han, J. (2008). Natural environment and cultural development of Northwest China in the Pre-Qin periods. Beijing: Cultural Relics Publishing House (in Chinese).

Hessl, A. E., Leland, C., Saladyga, T., \& Byambasuren, O. (2017). Hydraulic cities, colonial catastrophes, and nomadic empires: Human-environment interactions in Asia. In M. M. Amoroso, L. D. Daniels, P. J. Baker, \& J. J. Camarero (Eds.), Dendroecology: Tree-ring analyses applied to ecological studies (pp. 345-363). Cham: Springer International Publishing.

Hill, D. J. (2019). Climate change and the rise of the Central Asian Silk Roads. In L. E. Yang, H.-R. Bork, X. Fang, \& S. Mischke (Eds.), Socio-environmental dynamics along the historical Silk Road. Heidelberg, Germany: Springer-Nature Press.

Hu, R., Jiang, F.-Q., Ya-jun, W., Li, J.-L., Li, Y.-M., Ableki, A., et al. (2014). Arid ecological and geographical conditions in five countries of Central Asia. Arid Zone Research, 31(1), 1-12.

Invictus, I. (2006). History of Central Asia-An overview. www.allempires.com. Accessed in June 2018.

Issar, A. S., \& Zohar, M. (2004). Climate change, environment and civilization in the Middle East. Berlin: Springer Science \& Business Media.

Kázmér, M. (2019). Living with earthquakes along the Silk Road. In L. E. Yang, H.-R. Bork, X. Fang, \& S. Mischke (Eds.), Socio-environmental dynamics along the historical Silk Road. Heidelberg, Germany: Springer-Nature Press.

Leroy, S. A. G. (2006). From natural hazard to environmental catastrophe: Past and present. Quaternary International, 158, 4-12. 
Li, C.-X., Song, Y.-G., Qian, L.-B., \& Le-min, W. (2011a). History of climate change recorded by grain size at the Zhaosu Loess section in the Central Asia since the Last Glacial Period. Acta Sedimentologica Sinica, 29(6), 1170-1179.

Li, Q., Lu, H. Y., Zhu, L. P., Wu, N. Q., Wang, J. B., \& Lu, X. M. (2011b). Pollen-inferred climate changes and vertical shifts of alpine vegetation belts on the northern slope of the Nyainqentanglha Mountains (central Tibetan Plateau) since 8.4 kyr BP. Holocene, 21(6), 939-950.

Lioubimtseva, E., \& Henebry, G. M. (2009). Climate and environmental change in arid Central Asia: Impacts, vulnerability, and adaptations. Journal of Arid Environments, 73(11), 963-977.

Liu, C. L., Zhang, J. F., Jiao, P. C., \& Mischke, S. (2016). The Holocene history of Lop Nur and its palaeoclimate implications. Quaternary Science Reviews, 148, 163-175.

Liu, X. (2010). The Silk Road in world history. Oxford, UK: Oxford University Press.

Luneau, É. (2018). Climate change and the rise and fall of the Oxus civilization in Southern Central Asia (ca. 2300-1400 BCE) In L. E. Yang, H.-R. Bork, X. Fang, \& S. Mischke (Eds.), Socioenvironmental dynamics along the historical Silk Road. Heidelberg, Germany: Springer-Nature Press.

Mächtle, B., Hecht, S., Manke, N., Kromer, B., Lindauer, S., Li, C.-S., et al. (2019). The age and origin of Karez systems of Silk Road oases around Turpan, Xinjiang, P.R. of China. In L. E. Yang, H.-R. Bork, X. Fang, \& S. Mischke (Eds.), Socio-environmental dynamics along the historical Silk Road. Heidelberg, Germany: Springer-Nature Press.

Marston, J. M. (2015). Modeling resilience and sustainability in ancient agricultural systems. Journal of Ethnobiology, 35(3), 585-605. https://doi.org/10.2993/etbi-35-03-585-605.1.

Marten-Finnis, S. (2019). Mapping Bukhara: Steppe and Sown-Heritage and the understanding of urban neighbourhood principles in the light of Soviet ethnographic enquiry. In L. E. Yang, H.-R. Bork, X. Fang, \& S. Mischke (Eds.), Socio-environmental dynamics along the historical Silk Road (pp. 1948-1976). Heidelberg, Germany: Springer-Nature Press.

Mayewski, P. A., Rohling, E. E., Stager, J. C., Karlen, W., Maasch, K. A., Meeker, L. D., et al. (2004). Holocene climate variability. Quaternary Research, 62(3), 243-255.

McMichael, A. J. (2012). Insights from past millennia into climatic impacts on human health and survival. Proceedings of the National Academy of Sciences of the United States of America, 109(13), 4730-4737.

Mischke, S., Liu, C. L., Zhang, J. F., Zhang, C. J., Zhang, H., Jiao, P. C., et al. (2017). The world's earliest Aral-Sea type disaster: The decline of the Loulan Kingdom in the Tarim Basin. Scientific Reports, 7.

Mischke, S., Zhang, C., Liu, C., Zhang, J., Lai, Z., \& Long, H. (2019). Landscape response to climate and human impact in western China during the Han Dynasty. In L. E. Yang, H.-R. Bork, X. Fang, \& S. Mischke (Eds.), Socio-environmental dynamics along the historical Silk Road. Heidelberg, Germany: Springer-Nature Press.

Opała-Owczarek, M., \& Owczarek, P. (2019). Dry and humid periods reconstructed from tree rings in the former territory of Sogdiana (Central Asia) and their socio-economic consequences over the last millennium. In L. E. Yang, H.-R. Bork, X. Fang, \& S. Mischke (Eds.), Socio-environmental dynamics along the historical Silk Road. Heidelberg, Germany: Springer-Nature Press.

Panyushkina, I. P., Macklin, M. G., Toonen, W. H. J., \& Meko, D. M. (2019). Water supply and ancient society in the Lake Balkhash Basin: Runoff variability along the historical Silk Road. In L. E. Yang, H.-R. Bork, X. Fang, \& S. Mischke (Eds.), Socio-environmental dynamics along the historical Silk Road. Heidelberg, Germany: Springer-Nature Press.

Peregrine, P. N. (2017). Social resilience to climate-related disasters in ancient societies: A test of two hypotheses. Weather, Climate, and Society, 10(1), 145-161.

Porter, A. (2012). Mobile pastoralism and the formation of near eastern civilizations: Weaving together society. Cambridge: Cambridge University Press.

Pow, S. (2019). Climatic and environmental limiting factors in the Mongol Empire's westward expansion: Exploring causes for the Mongol withdrawal from Hungary in 1242. In L. E. Yang, H.-R. Bork, X. Fang, \& S. Mischke (Eds.), Socio-environmental dynamics along the historical Silk Road. Heidelberg, Germany: Springer-Nature Press. 
Rogers, J. D., Nichols, T., Emmerich, T., Latek, M., \& Cioffi-Revilla, C. (2012). Modeling scale and variability in human-environmental interactions in inner Asia. Ecological Modelling, 241, 5-14.

Rosen, A. M. (2007). Civilizing climate: Social responses to climate change in the ancient Near East. Lanham, Maryland, USA: AltaMira Press.

Sala, R. (2019). Quantitative evaluation of the impact on Aral Sea levels by anthropogenic water withdrawal and Syrdarya course diversion during the Medieval Period (1.0-0.8 ka BP). In L. E. Yang, H.-R. Bork, X. Fang, \& S. Mischke (Eds.), Socio-environmental dynamics along the Historical Silk Road. Heidelberg, Germany: Springer-Nature Press.

Shi, W., Liu, Y., \& Shi, X. (2017). Quantitative methods for detecting the impacts of climate change on the fluctuation of farming-pastoral ecotone boundaries in northern China. Acta Geographica Sinica, 72(3):407-419. https://doi.org/10.11821/dlxb201703004.

Sorg, A., Bolch, T., Stoffel, M., Solomina, O., \& Beniston, M. (2012). Climate change impacts on glaciers and runoff in Tian Shan (Central Asia). Nature Climate Change, 2(10), 725-731.

Spate, M. (2019). Reconsidering archaeological and environmental proxies for long term humanenvironment interactions in the Valley of Kashmir. In L. E. Yang, H.-R. Bork, X. Fang, \& S. Mischke (Eds.), Socio-environmental dynamics along the historical Silk Road. Heidelberg, Germany: Springer-Nature Press.

Staubwasser, M., \& Weiss, H. (2006). Holocene climate and cultural evolution in late prehistoricearly historic West Asia. Quaternary Research, 66(3), 372-387.

Tinner, W., \& Ammann, B. (2005). Long-term responses of mountain ecosystems to environmental changes: Resilience, adjustment, and vulnerability. In: U. M. Huber, H. K. M. Bugmann, \& M. A. Reasoner (Eds.), Global change and mountain regions: An overview of current knowledge (pp. 133-143). Netherlands, Dordrecht: Springer. https://doi.org/10.1007/1-4020-3508-X_14.

Tol, R. S. J., \& Wagner, S. (2010). Climate change and violent conflict in Europe over the last millennium. Climate Change, 99(1-2), 65-79.

Vyazov, L. A., Ershova, E. G., Ponomarenko, E. V., Gajewski, K., Blinnikov, M. S., \& Sitdikov, A. G. (2019). Demographic changes, trade routes, and the formation of anthropogenic landscapes in the Middle-Volga region in the first millennium AD. In L. E. Yang, H.-R. Bork, X. Fang, \& S. Mischke (Eds.), Socio-environmental dynamics along the historical Silk Road. Heidelberg, Germany: Springer-Nature Press.

Wilson, G. A. (2014). Community resilience: Path dependency, lock-in effects and transitional ruptures. Journal of Environmental Planning and Management, 57(1), 1-26.

Wu, Y. (1983). The nomadic world and farming world in the world history. Social Science of Yunnan, 1 (in Chinese).

Xoplaki, E., Luterbacher, J., Wagner, S., Zorita, E., Fleitmann, D., Preiser-Kapeller, J., et al. (2018). Modelling climate and societal resilience in the Eastern Mediterranean in the Last Millennium. Human Ecology, 46(3), 363-379.

Xu, A., Yang, L. E., Yang, W., \& Hillman, A. L. (2019). Resilience of the human-water interrelationship at the Southern Silk Road: Evolution of the northern catchment of Erhai Lake, China (1382-1912). In L. E. Yang, H.-R. Bork, X. Fang, \& S. Mischke (Eds.), Socio-environmental dynamics along the historical Silk Road. Heidelberg, Germany: Springer-Nature Press.

Yang, L. E., Bork, H.-R., Fang, X., Mischke, S., Weinelt, M., \& Wiesehöfer, J. (2019). On the paleoclimatic/environmental impacts and socio-cultural system resilience along the historical Silk Road. In L. E. Yang, H.-R. Bork, X. Fang, \& S. Mischke (Eds.), Socio-environmental dynamics along the historical Silk Road. Heidelberg, Germany: Springer-Nature Press.

Yang, L. E., Wiesehöfer, J., Bork, H.-R., \& Hoo, M. (2017). The role of environment in the sociocultural changes of the ancient Silk Road Area. Past Global Changes Magazine, 25(3), 165.

Yao, J.-Q., Yang, Q., Chen, Y.-N., Hu, W.-F., Liu, Z.-H., \& Zhao, L. (2013). Climate change in arid areas of Northwest China in past 50 years and its effects on the local ecological environment. China Journal of Ecology, 32(5), 1283-1291.

Zhang, D., Jim, C., Lin, C., He, Y., \& Lee, F. (2005). Climate change, social unrest and dynastic transition in Ancient China. Chinese Science Bulletin, 50(2), 137-144. 
Zhang, D. D., Lee, H. F., Wang, C., Li, B. S., Pei, Q., Zhang, J., et al. (2011). The causality analysis of climate change and large-scale human crisis. Proceedings of the National Academy of Sciences of the United States of America, 108(42), 17296-17301.

Zhang, D. D., Zhang, J., Lee, H. F., \& He, Y. Q. (2007). Climate change and war frequency in Eastern China over the last millennium. Human Ecology, 35(4), 403-414.

Zhao, Y., Liu, Y. L., Guo, Z. T., Fang, K. Y., Li, Q., \& Cao, X. Y. (2017). Abrupt vegetation shifts caused by gradual climate changes in central Asia during the Holocene. Science China Earth Sciences, 60(7), 1317-1327.

$\mathrm{Zu}$, R., Gao, Q., Qu, J., \& Qiang, M. (2003). Environmental changes of oases at southern margin of Tarim Basin. China Environmental Geology, 44(6), 639-644.

Open Access This chapter is licensed under the terms of the Creative Commons Attribution 4.0 International License (http://creativecommons.org/licenses/by/4.0/), which permits use, sharing, adaptation, distribution and reproduction in any medium or format, as long as you give appropriate credit to the original author(s) and the source, provide a link to the Creative Commons license and indicate if changes were made.

The images or other third party material in this chapter are included in the chapter's Creative Commons license, unless indicated otherwise in a credit line to the material. If material is not included in the chapter's Creative Commons license and your intended use is not permitted by statutory regulation or exceeds the permitted use, you will need to obtain permission directly from the copyright holder. 